www.ccsenet.org/journal.html

\title{
An Empirical Study on the Relationship between China's Economic Development and Environmental Quality------Testing China's Environmental Kuznets Curve
}

\author{
Gendi Wen \\ School of International Business, Beijing Foreign Studies University, Beijing 100089, China \\ E-mail: wengendi@gmail.com \\ Zhe Cao \\ Oriental College of Science \& technology, Hunan Agricultural University, Changsha 410128, China \\ E-mail: caozhe@gmail.com
}

\begin{abstract}
Since the reform and opening-up policy, China's economy has achieved a sustainable and fast growth. However, the traditional economic growth mode with high investments, high consumption, and high emissions causes a growing contradiction between China's economic growth and environment. How to select an economic growth way with the harmonious development of society, economy, ecology, and environment with the restriction of environment is meaningful in theory and practice. Whether there is a reverse U-shape relationship between the national income per capita and the environmental pressure affects the policy choice of economic growth mode. If there is a reverse U-shape relationship between the national income per capita and the environmental pressure, the government can only implement measures driving the economic growth. Once economy grows to certain degree, environmental pressure will decline naturally. However, there is not a reverse U-shape relationship between them, or although there is a reverse U-shape relationship, the national income per capita at the turning point is hard to realize, the development mode adopted by many developing countries that emphasizes on economic growth, polluting first, then improving, will do nothing but worsen the environment. The government should take action to change the economic growth mode, decreasing the pressure on environment caused by economic growth. Only by this way, can it realize the sustainable development of economy. This paper firstly analyzes and comments the empirical studies of Environmental Kuznets Curve (EKC), then makes regression on the national income per capita for years and the main pollutants indexes, analyzing the relationship between China's national income per capita and environmental pressure. An empirical study shows that the relationship between China's emission of main pollutants and the national income per capita does not follow a typical EKC.
\end{abstract}

Keywords: Economic growth, Resources and environment, Environmental Kuznets Curve (EKC)

\section{Introduction}

Since the industrial revolution, along with the fast growth of global economy, human has consumed considerable natural resources. Environment quality is worsening seriously. Macro economic theories begin to care about economic growth and environment. After the publication of The Limits to Growth by Mesdows in 1971, the relationship between economic growth and environment gained more and more attentions from people.

To study the relationship between economic growth and environment has extremely important policy meanings. If there is a contradictory relationship between economic growth and environmental pollution, the rational choice for human is to restrict the economic growth and protect the ecological environment in which human live. If there is a mutually promoting harmonious relationship between economic growth and environmental quality, the rational choice for human is to accelerate economic growth, because fast economic growth will directly lead to the improvement of environmental quality. If there is a reverse U-shape relationship between economic growth and environment, it means environmental degradation associates with economic development stage. Economic growth will benefit the improvement of environmental quality finally.

What's the relationship between China's economic growth and environmental quality? Whether the "development-first, treatment-second" mode is an irreplaceable way for developing countries? Is there alternative for China's development? After making an empirical analysis of the evolvement of the relationship between China's environment and economy in 20 years, this paper tries to give answers to these questions. 
This paper firstly analyzes and comments the Environmental Kuznets Curve's (EKC) empirical studies. Then, this paper makes regression on China's national income per capita and main pollutants indexes, analyzing and researching the relationship between China's national income per capita and environmental pressure.

\section{Literature review of EKC empirical studies}

\subsection{The mode's basic form and study result}

In recent ten years, lots of domestic and foreign scholars make considerable empirical studies on changes of environmental quality in economic growing process. Theses studies have the prominent commonness that all data are parallel data measured at different time points in different countries and they adopt the following mode to make regression on the relationship between environmental pressure $\mathrm{E}$ and national income per capita $\mathrm{Y}$.

$E_{i t}=\alpha+\beta_{1} Y_{i t}+\beta_{2} Y_{i t}^{2}+\beta_{3} Y_{i t}^{3}+\beta_{4} t+\beta_{5} Z_{i t}+e_{i t}$

Formula (1)

Here, $E_{i t}$ means the environmental pressure of country $i_{\text {at }}$ the time $t$. $Y_{i t}$ is the national income per capita in country $i_{\text {at }}$ the time $t$. $\alpha$ is the intercept of abscissas. $\beta$ is the parameter in estimation. $Z_{i t}$ means other factor

affecting environmental pressure except the income. $e_{i t}$ is the random error in normal distribution. According to different regression results, Model (1) can reflect seven kinds of environment-income relationship as follow in Figure 1 .

(1) $\beta_{1}>0, \beta_{2}=\beta_{3}=0$ : linear shape, monotone increasing, as the income rises, environmental pressure is increasing.

(2) $\beta_{1}<0, \beta_{2}=\beta_{3}=0$ : linear shape, monotone decreasing, as the income rises, environmental pressure is decreasing.

(3) $\beta_{1}>0, \beta_{2}<0, \beta_{3}=0$ : reverse U-shape, as the income reaches certain value, environmental pressure decreases as the income rises.

(4) $\beta_{1}<0, \beta_{2}>0, \beta_{3}=0$ : U-shape

(5) $\beta_{1}>0, \beta_{2}<0, \beta_{3}>0$ : N-shape, similar to the U-shape. But as the income rises further, environmental pressure increases again.

(6) $\beta_{1}<0, \beta_{2}<0, \beta_{3}>0$ : reverse N-shape, environmental pressure decreases firstly, then increases, and finally decreases.

(7) $\beta_{1}=\beta_{2}=\beta_{3}=0$ : horizontal line, the income does not affect environmental pressure.

Therefore, the reverse U-shape EKC is only one of seven results from the regression of Model (1).

Popular environmental quality indexes include $\mathrm{SO}_{2}$, suspended particulate, dust, $\mathrm{CO}, \mathrm{CO}_{2}, \mathrm{COD}$, pathogenic bacteria, and heavy metal. The study model usually adopts a quantity decreasing form, abstracting the influencing factors of environmental quality into the income. Some environmental quality indexes use the emission method, and some the environmental degradation index. As for the income, people may use the PPP method or the market rate. Besides, due to the different data used in studies, the empirical studies on EKC hypothesis result in different conclusions. Specific studies are shown in Table 1.

Here, the main studies are as follow:

(1) $\mathrm{SO}_{2}$

Grossmna and Krueger (1995) analyze the relationship between city air pollution and GNP per capita based on data of $\mathrm{SO}_{2}$ in 42 countries from 1977 to 1993, which are tested by the Global Environmental Monitoring System (GEMS) that is designed by World Health Organization and the United Nations Environment Programme. They find that the relationship between them is not in a reverse U-shape but N-shape. At the first and the second peak, the income per capita is respectively 4,100 US dollars and 14,000 US dollars. However, Panayotou (1993), Shafik (1992), Selden and Song (1995) think there is a reverse U-shape relationship between the two. In their studies, at the peaks, the income per capita is respectively 10,700 US dollars, 3,700 US dollars, and 5,900 US dollars.

(2) City air suspended particulate

According to studies of Grossmna and Krueger (1995), Selden and Song (1995), and Panayotou (1993), there is a reverse U-shape relationship between city air suspended particulate and income per capita. They calculate that the peak (income per capita) of the curve is respectively 16,000 US dollars, 9,800 US dollars, and 9,600 US dollars.

(3) Dust

Grossmna and Kurgeer (1995) agree that the dust-income per capita curve is in N-shape. Based on data of air suspended 
particulate in 37 countries, they calculate the income per capita at the first and the second peak is respectively 6,200 US dollars and 10,000 US dollars. Based on data from America, the number is respectively 4,700 US dollars and 10,000 US dollars.

(4) $\mathrm{NO}_{\mathrm{x}}$

Grossmna (1995) thinks that $\mathrm{NO}_{\mathrm{x}}$ has a reverse U-shape relationship with the income per capita. At the peak, the income per capita is 18,500 US dollars. Selden and Song (1995) and Panayotou (1994) also agree this idea. In their calculation, the income per capita at the peak is respectively 12,000 US dollars, and 5,500 US dollars. Khanna (2002) thinks it is a U-shape relationship.

(5) $\mathrm{CO}$

Grossmna (1995), Selden and Song (1995) find that CO-income per capita relationship curve is in reverse U-shape. In their calculation, the income per capita at the peak is respectively 22,800 US dollars and 6,200 US dollars.

(5) $\mathrm{CO}_{2}$

Shafik (1994) thinks that there is not a reverse U-shape relationship between $\mathrm{CO}_{2}$ and the income per capita. Holtz-Kani (1992) thinks that there is a reverse U-shape relationship between the two. By calculating the emission of $\mathrm{CO}_{2}$ per capita and the income per capita, he gets the income per capita at the peak is 35,400 US dollars. Based on the emission of per unit capital and the income per capita, the income per capita at the peak is $8,000,000$ US dollars. Khanna (2002) thinks that there is linear relationship between the two.

(7) Dissolved oxygen in water

Grossmna (1993) thinks that there is a reverse U-shape relationship between the two. The value at the peak is 8500 US dollars. Shafik (1994) thinks there is not a reverse U-shape relationship between the two. Along with the rise of income, the dissolved oxygen in water will increase continuously.

(8) Quantity of pathogenic bacteria in water

Shafik (1994) thinks there is an N-shape relationship between them. The value at the fist and second peak is respectively 1,400 US dollars and 11,400 US dollars. Grossmna and Krueger (1995) think that there is a reverse U-shape relationship between them. The value at the peak is 8,000 US dollars.

(9) Total quantity of bacteria in water

Grossmna and Krlleger (1995) think that there is an N-shape relationship between them. The value at the first and the second peak is respectively 3,034 US dollars and 8,000 US dollars.

\subsection{Comments on empirical studies of EKC hypothesis}

From analyses above, we know that most EKC empirical studies focus on air quality indexes and water environment indexes in some cities. These environment indexes tend to worsen firstly and then improve along with economic growth in general. Most pollutants have a reverse U-shape relationship with the income per capita. But in different studies, the value at the peak is far different. Meanwhile, the pollutants that have a reverse U-shape relationship with the income per capita can be degraded in environment naturally. Besides, most are local pollutants. These pollutants associate directly with local residents' health and welfare. So, it is easy for these pollutants being treated properly. As for the global environmental problem or the environmental problem that polluters are far from victims in space and time, the economic growth does not exert a significant effect on the improvement of environment. For example, the emission of greenhouse gas, the loss of water and oil in upstream area increasing the possibility of flooding in downstream area, contemporary people destroying environmental resources threatens the sustainable development. In addition, empirical studies show that some pollutants have a N-shape relationship with the income per capita. To sum up, EKC empirical studies result in different conclusions. The author thinks that reasons for the differences of conclusions include these aspects as follow.

Firstly, as selecting environmental pressure indexes, some researchers take the concentration of pollutants as indexes, but others take the emission as indexes. Even for the same pollutant, due to the different way reflecting environmental pressure, it will cause different results in research.

Secondly, in researching and making regression, whether the explanatory variables increase or not, and to add different indexes will lead to different results.

Thirdly, due to the shortage of materials, present research samples have more limits. Western scholars usually use the cross-section data from developed countries and developing countries to make analysis in researching EKC. The selection and scope of samples affect the research results directly. Besides, samples cover a narrow area and short time period.

Fourthly, the calculation of income per capita is different. Trans-national cross-section data associates with the 
exchange rate. Different countries may use different indexes to calculate the GDP per capita, such as current price or the price at certain fixed year, which will lead to different results.

Fifthly, presently most empirical studies focus on one single pollutant index, without researching the general condition of environmental quality. Along with the development of economy, the material base for economic activity will change. Environmental pollution may turn into other kind of pollution from one pollutant. Therefore, although some pollutant indexes decrease, the general environmental quality is not improved. For example, Mc-Giliivrya (1993) studies 22 OECD countries by comprehensive environmental indexes based on 12 environmental indexes and finds that there is not a significant correlation between income and environmental quality.

Sixthly, at present, the income per capita at the turning point of EKC is mostly the social average income. Because the distribution of social income is not equal in practice, more people locate under the average than that above the average. Therefore, in analyzing the relationship between the growth and environment, to choose the average income as an index is unreasonable. The income median is a more reasonable index. But seldom it is used in studies at present.

\section{Empirical test on China's environmental EKC}

Whether there is a reverse U-shape relationship between China's income per capita and environmental pressure? If there is, what is the value at the turning point? In this part, we will use the EKC model to make a regression analysis of China's income per capita and main pollutants.

\subsection{Data selection}

In order to compare with present researches, we can select $\mathrm{SO}_{2}$, waste water, waste gas, and solid waste as environmental pressure indexes. Each pollutant has two kinds of data, namely emission and concentration. Data of emission is calculated by practical energy consumption multiplying emission coefficient. Data of concentration is from practical measure. Although data of concentration is exacter data of emission, it is improper to use concentration data to analyze the relationship between environmental pressure and the GDP per capita. Firstly, concentration data merely reflects the pollution at the monitoring spots, which mostly locate in large cities, where the income per capita is usually different from the GDP per capita. Secondly, people pay more attention to cities' environmental quality. Many polluting industries move toward some undeveloped areas around cities. This industrial transfer in one country will affect the concentration of pollutants at the monitoring spot but not the GDP per capita. Besides, changes of climate have effects on the data of concentration. For example, rain can shorten the moving distance of pollutants in air. At the year with more rain, cities exporting pollutants have higher concentration of pollutants, while cities importing pollutants have lower concentration of pollutants. These changes have nothing to do with the income per capita apparently. So, in order to make the regression more precise, we choose the emission data to make regression on EKC. Sample data are in Table 2 as follow.

\subsection{Standard model estimation and result analysis}

In order to test the relationship between China's pollution emission and economic growth, we build an econometric testing model as follow:

$$
\begin{aligned}
& \operatorname{Ln} P_{x}=a_{0}+a_{1} \operatorname{LnINC}+a_{2}(\operatorname{LnINC})^{2}+\varepsilon_{0} \\
& \operatorname{Ln}\left(P_{x} / N\right)=a_{0}+a_{1} \operatorname{LnINC}+a_{2}(\operatorname{LnINC})^{2}+\varepsilon_{0}
\end{aligned}
$$

Here, INC is the national income per capita. Px is the emission of pollutant. $\mathrm{N}$ is the number of population. Table 3 is a result of making regression on the time sequence data by the regression model in SPSS.

From the Table 3, we know that the determination coefficients of the four indexes, namely emission of waste water, waste water emission per capita, emission of waste gas, and waste gas emission per capita, are all above 0.8, which indicates a relatively positive fitting effect. The determination coefficient $\mathrm{R}^{2}$ of emission of $\mathrm{SO}_{2}, \mathrm{SO}_{2}$ emission per capita, emission of solid waste, and solid waste emission of per capita, are relatively smaller. Especially the determination coefficients of emission of $\mathrm{SO}_{2}$ and $\mathrm{SO}_{2}$ emission per capita are lower than 0.5 , which means the fitting effect is unsatisfying.

From the Table 3, we find that the eight indexes have the characteristics of U-shape curve, which is not in accordance with EKC. Although the determination coefficients of four indexes, namely emission of SO2, $\mathrm{SO} 2$ emission per capita, emission of solid waste, and solid waste emission per capita, are smaller. Especially the determination coefficients of $\mathrm{SO} 2$ emission per capita and emission of $\mathrm{SO} 2$ are lower than 0.5 , and the fitting effect is not satisfying. Their practical curves are in a mess. In a short term, we could not identify their real tendency. They should be researched in a longer time period. In general, the fitting effects show that the relationship between China's main pollutants emission and changes of GDP per capita has no typical characteristics of EKC changes.

\section{Conclusion}

According to the EKC hypothesis, environmental degradation is only a stage phenomenon in the process of economic 
growth. As economy grows to certain degree, environmental pressure will be released gradually. Economic growth can reduce environmental pressure naturally. But this study indicates that although the rise of main pollutants emission tends to be slow, the emission of main pollutants has no typical characteristics of EKC. The emission of many pollutants keeps in rising along with the economic development. Due to the increasing demand for energies in developing China's heavy industry, emission of $\mathrm{SO}_{2}$ and other pollutants is rising. Maybe as the time sequence is longer, a turning point in EKC will appear. But at present, the relationship between China's economic growth and resources and environmental pressure is not in accordance with the EKC hypothesis. Therefore, to apply the EKC theory to China's economic growth simply may cause serious consequences and cost a lot.

At present, many developing countries are making choices between economic development and environmental protection. China is not an exception. Therefore, it is impossible to solve the environmental issue originated from economic growth completely by economic growth itself. To solve the environmental pressure in economic growth, the government must choose the right path for economic growth. If without understanding this point, it is hard for China's future economic growth decreasing the environmental pressure, and the economic growth path will not turn toward the direction of sustainable development naturally. In this sense, China has more to do on the sustainable development way.

\section{References}

Chen, Desheng., Li, Chunqing. \& Wen, Gendi. (2008). China Macro Economy Analysis Frame. Beijing: Economics Science Press.

Grossman, G.M. \& A.B. Kruger. (1995). Economic growth and the environment. Quarterly Journal of Economics. No.112. p353-378.

Holtz-Eakin, D. \& T.M. Selden. (1995). Stoking the fires? CO2 emissions and economic growth. Journal of Public Economics. No. 57. p85-101.

Kaufmann, P.K. (1998). The determinants of atmospheric SO2 concentrations: resonsidering the EKC. Ecological Economics. No. 25. p209-220.

Neha Khanna. (2002). The Income elasticity of non-point source air pollutants: revisiting the environmental Kruznets Curve. Economics Letters. No. 77. p387-392.

Panayotou, T. (1993). Empirical tests and policy analysis of environmental degradation at different stages of economic development, World Employment Programme Research Working Paper WEP 2-22/WP238. January, International Labor Office, Geneva.

Selden, T.M. \& D.S. Song. (1994). Environmental quality and development: is there a Kuznets Curve for air pollution emissions?. Journal of Environment Economics and Management. No. 27. p147-162.

Shafix, N. \& Bandyopqhyay, S. (1992). Economic growth and environment quality: time series and cross-country evidence. Background Paper for the World Development Report 1992. World Bank, Washington, DC.

Stern, D.I., M.S. Common \& E.B. Barbier. (1996). Economic growth and environmental degradation: a critique of the EKC. World Development. No.24. p1151-1160.

Torras, M. \& J.K. Boyce. (1998). Income, inequality and pollution: a reassesement of the EKC. Ecological Economics. No. 25. p147-160. 
Table 1. Empirical studies of the relationship between the income per capita and environmental quality

\begin{tabular}{|c|c|c|c|c|}
\hline Pollutant & Researcher & Curve & $\begin{array}{l}\text { Value at the first } \\
\text { peak (US dollar) }\end{array}$ & $\begin{array}{l}\text { Value at the } \\
\text { second peak } \\
\text { (US dollar) }\end{array}$ \\
\hline \multirow[t]{6}{*}{$\mathrm{SO}_{2}$} & Grossmna and Krueger (1991) & N-shape & 4,100 & 14,000 \\
\hline & Sharflik (1994) & Reverse U-shape & 3,700 & \\
\hline & Grossman (1993) & Cubic equation & 4,100 & \\
\hline & Grossman and Krueger(1995) & N-shape & 13,400 & 14,000 \\
\hline & Selden and Song (1994) & Reverse U-shape & 8,900 & \\
\hline & Panayaotou (1993) & Reverse U-shape & 10,700 & \\
\hline \multirow[t]{6}{*}{$\begin{array}{l}\text { Suspended } \\
\text { particualte }\end{array}$} & Grossman and Krueger (1991) & $\begin{array}{l}\text { Linear equation, } \\
\text { growing downward }\end{array}$ & & \\
\hline & Sharflik (1994) & Reverse U-shape & 3,300 & \\
\hline & Grossman (1993) & Reverse U-shape & 16,000 & \\
\hline & Grossman and Krueger (1995) & & & \\
\hline & Selden and Song (1994) & Reverse U-shape & 9,800 & \\
\hline & Panayaotou (1993) & Reverse U-shape & 9,600 & \\
\hline \multirow[t]{3}{*}{ Dust } & Grossman and Krueger (1991) & N-shape & 5,000 & 10,000 \\
\hline & Grossman (1993) & N-shape & 4,700 & 10,000 \\
\hline & Grossman and Krueger (1995) & N-shape & 6,200 & 10,000 \\
\hline \multirow[t]{4}{*}{$\mathrm{NO}_{\mathrm{x}}$} & Grossman(1993) & Reverse U-shape & 18,500 & \\
\hline & Selden and Song (1994) & Reverse U-shape & 12,000 & \\
\hline & Panayaotou (1993) & Reverse U-shape & 5,500 & \\
\hline & Khanna (2002) & U-shape & & \\
\hline \multirow[t]{2}{*}{$\mathrm{CO}$} & Grossman (1993) & Reverse U-shape & 22,800 & \\
\hline & Selden and Song (1994) & Reverse U-shape & 6,200 & \\
\hline \multirow[t]{5}{*}{$\mathrm{CO}_{2}$} & Sharflik (1994) & $\begin{array}{l}\text { Linear equation, } \\
\text { growing upward }\end{array}$ & & \\
\hline & Holtz-Eakin and Selden (1995) & & & \\
\hline & Emission per capita & Reverse U-shape & 35,400 & \\
\hline & Emission per unit capital & Reverse U-shape & $8,000,000$ & \\
\hline & Khanna (2002) & $\begin{array}{l}\text { Linear equation, } \\
\text { growing upward }\end{array}$ & & \\
\hline \multirow[t]{3}{*}{$\begin{array}{l}\text { Dissolved } \\
\text { oxygen in water }\end{array}$} & Sharflik (1994) & $\begin{array}{l}\text { Linear equation, } \\
\text { growing upward }\end{array}$ & & \\
\hline & Grossman (1993) & Reverse U-shape & 8,500 & \\
\hline & Grossman and Krueger (1995) & Reverse U-shape & 2,703 & \\
\hline \multirow{3}{*}{$\begin{array}{l}\text { Quantity of } \\
\text { pathogenic } \\
\text { bacteria in water }\end{array}$} & Sharflik (1994) & N-shape & 1,400 & 11,400 \\
\hline & Grossman (1993) & Reverse U-shape & 8,500 & \\
\hline & Grossman and Krueger (1995) & Reverse U-shape & 8,000 & \\
\hline \multirow{2}{*}{$\begin{array}{l}\text { Total quantity of } \\
\text { bacteria in water }\end{array}$} & Grossman (1993) & Cubic equation & & \\
\hline & Grossman and Krueger (1995) & N-shape & 3,034 & 8,000 \\
\hline
\end{tabular}


Table 2. Relevant data estimated by China's EKC

\begin{tabular}{|c|c|c|c|c|c|}
\hline Year & $\begin{array}{l}\text { Emission of } \\
\text { industrial waste } \\
\text { water }(10,000 \text { ton })\end{array}$ & $\begin{array}{l}\text { Emission of waste gas } \\
(100 \text { million cubic } \\
\text { meter })\end{array}$ & $\begin{array}{lr}\text { Emission } & \text { of } \\
\text { industrial } & \mathrm{CO}_{2} \\
(10,000 \text { ton }) & \end{array}$ & $\begin{array}{l}\text { Emission of solid } \\
\text { waste } \quad(10,000 \\
\text { ton) }\end{array}$ & $\begin{array}{l}\text { National income } \\
\text { per capita } \\
\text { (RMB/capita) }\end{array}$ \\
\hline 1989 & 2574009 & 73970 & 1100 & 10000 & 1160.5 \\
\hline 1990 & 2602380 & 69679 & 1250 & 13283 & 1354.1 \\
\hline 1991 & 2637531 & 77275 & 1412 & 8719 & 1508.4 \\
\hline 1992 & 2683886 & 82380 & 1523 & 8545 & 1637.2 \\
\hline 1993 & 2520945 & 83065 & 1565 & 5265 & 1884.4 \\
\hline 1994 & 2486861 & 85380 & 1494 & 4767 & 2299 \\
\hline 1995 & 2356608 & 101415 & 1165 & 3376 & 2975.1 \\
\hline 1996 & 2338534 & 104787 & 1323 & 2587 & 4014 \\
\hline 1997 & 2194919 & 109604 & 1292.5 & 919 & 4938.1 \\
\hline 1998 & 2155111 & 97463 & 1341.42 & 1932 & 5731.3 \\
\hline 1999 & 2218943 & 123407 & 1405.02 & 2242 & 6281.3 \\
\hline 2000 & 2058881 & 111196 & 1363.57 & 1690 & 6654.7 \\
\hline 2001 & 1883296 & 113375 & 1362.63 & 1549 & 7011 \\
\hline 2002 & 2006331 & 121203 & 1593.02 & 7048 & 7732.2 \\
\hline 2003 & 1973036 & 126807 & 1460.09 & 3880 & 8467.5 \\
\hline 2004 & 1942405 & 138145 & 1615.32 & 3186 & 9271.5 \\
\hline 2005 & 2026282 & 160863 & 1566 & 2894 & 10460.2 \\
\hline 2006 & 2071885 & 175257 & 1561.98 & 2635.21 & 12349.3 \\
\hline 2007 & 2122527 & 198906 & 1791.56 & 1940.91 & 14068.6 \\
\hline 2008 & 2211425 & 237696 & 1891.4 & 1761.95 & 15477.3 \\
\hline
\end{tabular}

Table 3. The conic model estimation results of national income per capita and pollutants emission

\begin{tabular}{|c|c|c|c|c|c|}
\hline $\operatorname{Ln} P_{x}$ or $\operatorname{Ln}\left(P_{x} / N\right)$ & $a_{0}$ & $a_{1}$ & $a_{2}$ & $R^{2}$ & F test \\
\hline $\begin{array}{l}\text { Emission of waste } \\
\text { water }\end{array}$ & $\begin{array}{l}18.3388 \\
(12.511)\end{array}$ & $\begin{array}{l}-0.8117 \\
(-2.199)\end{array}$ & $\begin{array}{l}0.0432 \\
(1.876)\end{array}$ & 0.830 & 41.414 \\
\hline $\begin{array}{l}\text { Waste water emission } \\
\text { per capita }\end{array}$ & $\begin{array}{l}7.5666 \\
(5.320)\end{array}$ & $\begin{array}{l}-0.9625 \\
(-2.688)\end{array}$ & $\begin{array}{l}0.0478 \\
(2.140)\end{array}$ & 0.932 & 115.694 \\
\hline Emission of waste gas & $\begin{array}{l}18.4518 \\
(5.021)\end{array}$ & $\begin{array}{l}-2.1057 \\
(-2.276)\end{array}$ & $\begin{array}{l}0.1543 \\
(2.674)\end{array}$ & 0.881 & 62.660 \\
\hline $\begin{array}{l}\text { Waste gas emission } \\
\text { per capita }\end{array}$ & $\begin{array}{l}7.6796 \\
(2.189)\end{array}$ & $\begin{array}{l}-2.2565 \\
(-2.555)\end{array}$ & $\begin{array}{l}0.1589 \\
(2.885)\end{array}$ & 0.840 & 44.685 \\
\hline Emission of $\mathrm{SO}_{2}$ & $\begin{array}{l}11.0788 \\
(3.610)\end{array}$ & $\begin{array}{l}-1.0680 \\
(-1.382)\end{array}$ & $\begin{array}{l}0.0731 \\
(1.516)\end{array}$ & 0.477 & 7.762 \\
\hline $\begin{array}{lll}\mathrm{SO}_{2} & \text { emission } & \text { per } \\
\text { capita } & & \end{array}$ & $\begin{array}{l}0.3066 \\
(0.103)\end{array}$ & $\begin{array}{l}-1.2187 \\
(-1.623)\end{array}$ & $\begin{array}{l}0.0777 \\
(1.659)\end{array}$ & 0.176 & 1.816 \\
\hline $\begin{array}{l}\text { Emission of solid } \\
\text { waste }\end{array}$ & $\begin{array}{l}51.9280 \\
(3.695)\end{array}$ & $\begin{array}{l}-10.4379 \\
(-2.950)\end{array}$ & $\begin{array}{l}0.6153 \\
(2.788)\end{array}$ & 0.622 & 13.999 \\
\hline $\begin{array}{l}\text { Solid waste emission } \\
\text { per capita }\end{array}$ & $\begin{array}{l}41.1558 \\
(2.929)\end{array}$ & $\begin{array}{l}-10.5887 \\
(02.994)\end{array}$ & $\begin{array}{l}0.6199 \\
(2.810)\end{array}$ & 0.666 & 16.920 \\
\hline
\end{tabular}


E

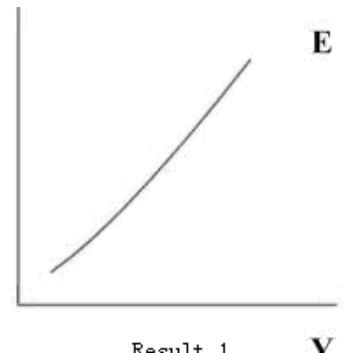

E

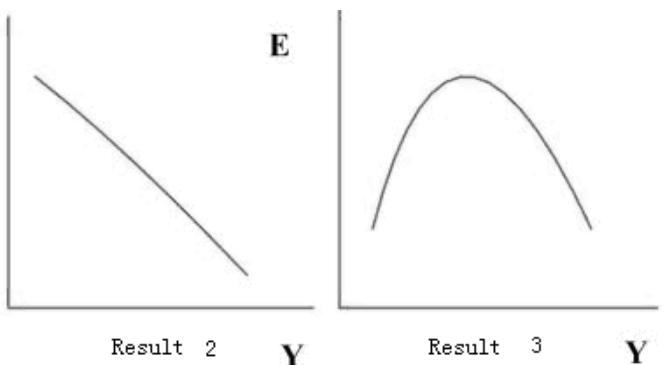

E

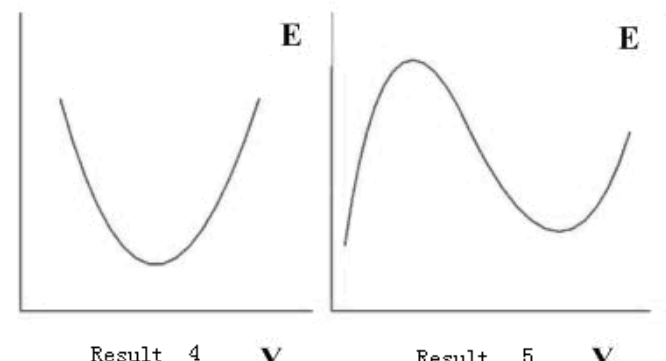

E

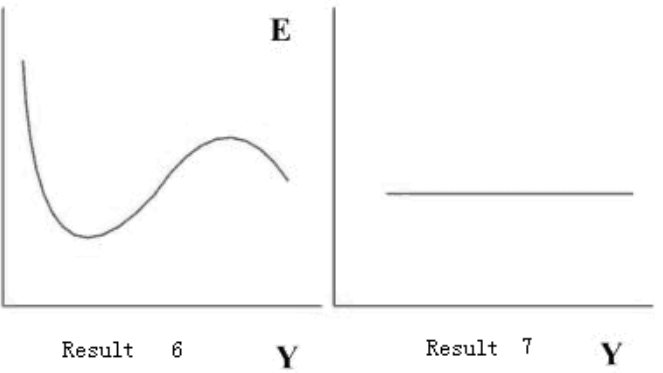

Figure 1. The Different Relationship between Environmental Pressure and National Income per Capita 